\title{
DNA cytosine methylation profile in various cancer-related genes is altered in cultured rat hepatocyte cell lines as compared with primary hepatocytes
}

\author{
KIYOSHI ASADA ${ }^{1,3}$, RUMIKO ASADA ${ }^{3}$, HITOSHI YOSHIJI ${ }^{1}$, \\ HIROSHI FUKUI ${ }^{1}$, ROBERT A. FLOYD ${ }^{3}$ and YASHIGE KOTAKE ${ }^{2,3}$ \\ ${ }^{1}$ Third Department of Internal Medicine, Nara Medical University, Kashihara Nara; ${ }^{2}$ Kyoto University \\ International Innovation Center, Uji, Kyoto, Japan; ${ }^{3}$ Free Radical Biology and Aging \\ Research Program, Oklahoma Medical Research Foundation, Oklahoma City, OK, USA
}

Received December 13, 2005; Accepted January 7, 2006

\begin{abstract}
We determined the DNA cytosine methylation status in the promoter $\mathrm{CpG}$ islands of eight cancer-related genes (p16, Socs-1, Rassf1A, Hic-1, Dlc-1, Timp-1, Timp-2, and Timp-3) in five rat hepatocyte cell lines, including normal cell lines (Clone 9 and CWSV-1) and tumor cell lines (H4-IIE-C3, MH1C1, and McA-RH7777). The experimental methods used to assess the methylation profile were methylationspecific PCR (MSP) and methylation-sensitive digestion combined with PCR. The results were compared with the methylation status of rat primary hepatocytes. To evaluate methylation-mediated gene induction/silencing, the expression of gene transcripts was semi-quantitatively assessed using RT-PCR. In primary cells, the CpG islands of all genes tested were unmethylated. In contrast, there was at least one hypermethylated gene in the cultured cell lines. Three genes ( $p 16$, Socs-1 and Rassf1A) were hypermethylated in Clone 9 cells; among the other five genes, three genes (Hic-1, Timp-1 and Timp-3) were hypermethylated in the CWSV-1 cell lines and two genes (Dlc-1 and Timp-2) were hypermethylated only in the tumor cell lines. The methylation status in some of the tested genes was altered at an early stage of cell culture as compared to primary cells. It is also noteworthy that hypermethylation in Socs-1, Rassf1, Hic-1, and Timp-3 was widespread among the cell lines tested, but not in the primary cells and Clone 9 cells. This study suggests that a cautious approach is required when cell lines are utilized to study methylation-related carcinogenic, metastatic or tumoricidal mechanisms.
\end{abstract}

Correspondence to: Dr Kiyoshi Asada, Third Department of Internal Medicine, Nara Medical University, 840 Shijo-cho, Kashihara, Nara 634-8521, Japan

E-mail: kasada@naramed-u.ac.jp

Key words: DNA cytosine methylation, hepatocyte, p16, Socs-1, Rassf1A, Hic-1, Dlc-1, Timp-1, Timp-2, Timp-3, Clone 9 and CWSV-1

\section{Introduction}

Established cell lines have been employed in the study of carcinogenic, metastatic, and tumoricidal mechanisms (1-3). However, it is possible that the carcinogenic mechanism found in cell lines may not be the same in vivo $(4,5)$. Also, tumoricidal agents that are effective in cancer cell lines may not necessarily be effective cancer-killing agents in vivo (6). We speculate that the difference in epigenetic DNA cytosine methylation status in cell lines and primary cells may play a role in such a discrepancy.

Epigenetic DNA cytosine methylation is believed to be one of the root causes of cancer. Indeed, in hepatocellular carcinoma (HCC), some cancer-related genes have been shown to be aberrantly methylated. For example, in human HCC, epigenetic changes of tumor suppressor genes have been demonstrated in p16/retinoblastoma (RB) and p53/p21 pathways $(7,8)$. In a rat model of HCC, i.e. dietary choline deficiency-induced HCC, it has been shown that promoter $\mathrm{CpG}$ islands in several tumor-suppressor genes and oncogenes are aberrantly methylated in tumor tissues (9-15). There is a cellular model of rat HCC, where CWSV-1 cells have been shown to become tumorigenic when cultured in cholinedeficient medium $(16,17)$. In our preliminary experiment using CWSV-1 cells, we found that the DNA methylation profiles of some cancer-related genes are altered as compared with primary cells even before culturing in choline-deficient conditions. Such observation prompted us to determine DNA cytosine methylation profiles in available rat hepatocyte cell lines.

We selected three normal rat hepatocyte cells and cell lines (primary, Clone 9, and CWSV-1) and three tumor hepatocyte cell lines (H4-II-E-C3, MH1C1, and McA-RH7777) and determined the methylcytosine content in the promoter $\mathrm{CpG}$ islands of eight genes; p16 (7), Suppressor of cytokine signaling-1 (Socs-1) (18), RAS association domain family $1 \mathrm{~A}$ (Rassf1A) (19), Hypermethylated in cancer-1 (Hic-1) (20), Deleted in liver cancer-1 (Dlc-1) (21), and Tissue inhibitor of metalloproteinases (Timp-1, Timp-2 and Timp-3) (22). Previously, these genes have been shown to be aberrantly methylated and silenced in the tissue of various cancers, and 
Table I. Rat hepatocyte cell lines.

\begin{tabular}{llcll}
\hline Cell line & ATCC no. & Gender & Normal/tumor & Description \\
\hline Primary & & $\mathrm{M}$ & $\mathrm{N}$ & From adult male Wistar rats \\
Clone 9 & CRL-1439 & $\mathrm{M}$ & $\mathrm{N}$ & Epithelial cell line from a young male rat \\
CWSV-1 & & $\mathrm{M}$ & $\mathrm{N}$ & p53 inactivated by large antigen \\
H4-II-E-C3 & CRL-1600 & $\mathrm{M}$ & $\mathrm{T}(\mathrm{HCC})^{\mathrm{a}}$ & $(55)$ \\
MH1C1 & CCL-144 & $\mathrm{F}$ & $\mathrm{T}(\mathrm{HCC})$ & Established from the transplantable Morris hepatoma \\
McA-RH7777 & CRL-1601 & $\mathrm{F}$ & $\mathrm{T}(\mathrm{HCC})$ & Established from the transplantable Morris hepatoma \\
\hline${ }^{\mathrm{a} H C C}$, hepatocellular carcinoma. & & & \\
\hline
\end{tabular}

the causal relationship to carcinogenesis was demonstrated. We employed methylation-specific PCR (MSP) and methylation-sensitive digestion combined with PCR for the assessment of methylation. The results indicated that there were significant alterations in methylation status compared with primary cells in all cell lines tested. Considering that such alterations may not be limited to rat hepatocytes, we believe that these data would serve as a cautionary note when established cell lines are used to study methylation-related carcinogenic, metastatic or tumoricidal mechanisms.

\section{Materials and methods}

Cell lines and genomic DNA/total RNA extraction. The primary cells and cell lines used in this study are listed in Table I together with brief descriptions. Primary rat hepatocyte cells were isolated from adult male Wistar rats by following the animal experiment protocol approved by the Institutional Animal Care and Use Committee (IACUC) at the Oklahoma Medical Research Foundation. Rat livers were cut into pieces in the medium and partially digested with collagenase, and cells were isolated with filtration. The five rat hepatocyte cell lines used in this study are listed in Table I. The CWSV-1 cell line, a cellular model of choline deficiencyinduced hepatocarcinogenesis, was a gift from Dr Hariett Isom, Pennsylvania State University, University Park, PA, USA. Other cells were purchased from the American Type Culture Collection (ATCC; Manassas, VA, USA). Cells were cultured in the medium as specified in the previous report or ATCC's instructions. Chemicals for medium preparation were purchased from Sigma Chemical Company (St. Louis, MO). Cells were harvested after less than 10 passages when stable division was accomplished. Some cells were harvested after a prolonged culture period to determine the age dependence of methylation status. Genomic DNA was extracted using a Qiagen DNeasy kit (Qiagen, Crawley, UK), and total RNA was extracted with Tri reagent (Sigma Chemical Co.). The genomic structures of the eight tumorrelated genes are illustrated in Fig. 1.

Methylation-specific PCR. Methylation analysis for selected genes (except Timp-1) was performed by methylationspecific PCR (MSP) of sodium bisulfite-treated DNA as described previously (23). Briefly, genomic DNA was digested by restriction enzyme into shorter fragments and PCRamplified followed by chemical treatment with sodium bisulfite. To confirm the specificity, genomic DNA from the

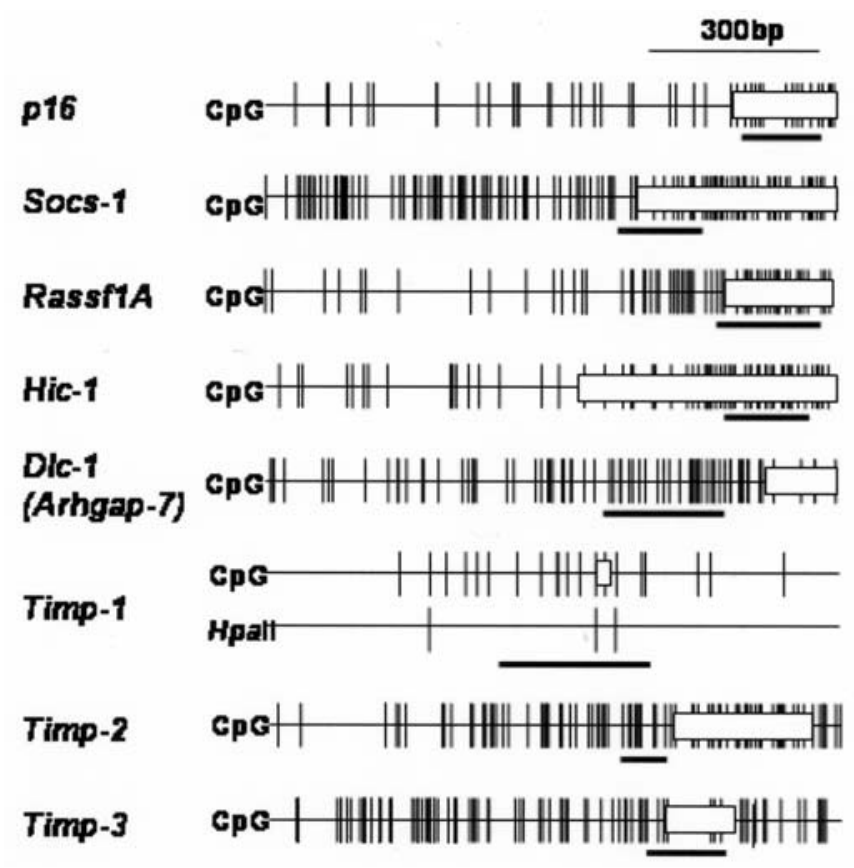

Figure 1. Genomic structures of tumor-related genes. Each short tick shows a single CpG site or HpaII-sensitive site, and blank boxes show Exon1. PCR (MSP and PCR after digestion) was performed at the region marked with thick horizontal lines.

primary cells was artificially methylated by SssI methylase and used as a positive control primer for the methylated sequence. All primer sets for unmethylated sequences can amplify PCR products from primary cell DNA. Primers were custom synthesized by the Molecular Biology Resource Facility, University of Oklahoma Health Sciences Center, Oklahoma City, OK, USA. PCR conditions, primer sequences and GenBank accession numbers are shown in Table II. Primer sequences for the $p 16$ gene are the same as previously reported (24). Densitometric analysis was performed using an imaging workstation (NucleoTech Corporation, Hayward, CA, USA).

Methylation-sensitive digestion and PCR. This method was applied specifically to determine Timp-1 gene methylation. After genomic DNA was digested by the restriction enzyme HpaII (methylation-sensitive) or MspI (methylation insensitive), the product was PCR amplified using primers specific for the methylated sequence. The primer sequences of Timp- 1 were 
Table II. Primer sequences for MSP.

\begin{tabular}{|c|c|c|c|c|}
\hline Gene & GenBank no. & $\mathrm{U} / \mathrm{M}$ & Primer sequence $\left(5^{\prime} \rightarrow 3^{\prime}\right)$ & $\begin{array}{c}\text { Annealing } \\
\text { temperature }\left({ }^{\circ} \mathrm{C}\right)\end{array}$ \\
\hline \multirow[t]{4}{*}{ p16 } & \multirow[t]{4}{*}{ AB081658 } & $\mathrm{U}$ & GTGAATTTGAGGAGAGTGATTTG & \multirow[t]{2}{*}{55} \\
\hline & & $\mathrm{U}$ & СААААСАТТТААТААААССССАА & \\
\hline & & M & AATTCGAGGAGAGCGATTCG & \multirow[t]{2}{*}{60} \\
\hline & & M & AACGTTTAATAAAACCCCGA & \\
\hline \multirow[t]{4}{*}{ Socs-1 } & \multirow[t]{4}{*}{$\mathrm{AJ} 243123$} & $\mathrm{U}$ & TTTTTATTAGTGTAGTTTTGGAT & \multirow[t]{2}{*}{55} \\
\hline & & $\mathrm{U}$ & AAAAATAACTCTAACCACCA & \\
\hline & & M & TTTTTATTAGCGTAGTTTCGGAC & \multirow[t]{2}{*}{55} \\
\hline & & M & GAAAATAACTCTAACCGCCG & \\
\hline \multirow[t]{4}{*}{ Rassf1A } & \multirow[t]{4}{*}{ NW_047801 } & $\mathrm{U}$ & TTTGATTGGGTTATGTTGGT & \multirow[t]{2}{*}{55} \\
\hline & & $\mathrm{U}$ & AATAACCACAACCCAAAACA & \\
\hline & & M & TTTGATCGGGTTATGTCGGC & \multirow[t]{2}{*}{60} \\
\hline & & M & GATAACCACGACCCGAAACG & \\
\hline \multirow[t]{4}{*}{ Hic-1 } & \multirow[t]{4}{*}{ NW_047336 } & $\mathrm{U}$ & TGTGTTGTTTTTTGTTTGTT & \multirow[t]{2}{*}{55} \\
\hline & & $\mathrm{U}$ & ACATCTACCAATTCAAACCA & \\
\hline & & M & TGCGTTGTTTTTCGTTCGTC & \multirow[t]{2}{*}{60} \\
\hline & & M & ACGTCTACCGATTCGAACCG & \\
\hline \multirow[t]{4}{*}{ Dlc-1 (Arhgap-7) } & \multirow[t]{4}{*}{ NW_047473 } & $\mathrm{U}$ & GTTTTTGTTGTTGGAGTTGT & \multirow[t]{2}{*}{55} \\
\hline & & $\mathrm{U}$ & ATAATCAAAATCCCACATCA & \\
\hline & & M & GTTTTCGTTGTTGGAGTCGC & \multirow[t]{2}{*}{60} \\
\hline & & M & AATAATCGAAATCCCACGTCG & \\
\hline \multirow[t]{4}{*}{ Timp-2 } & \multirow[t]{4}{*}{ NW_047344 } & $\mathrm{U}$ & GGTAGTGGAGGAGTTGAGTT & \multirow[t]{2}{*}{60} \\
\hline & & $\mathrm{U}$ & ACAAAACAATACACCCAACA & \\
\hline & & M & GGTAGCGGAGGAGTCGAGTC & \multirow[t]{2}{*}{60} \\
\hline & & M & GCAAAACAATACACCCGACG & \\
\hline \multirow[t]{4}{*}{ Timp-3 } & \multirow[t]{4}{*}{ NW_047773 } & $\mathrm{U}$ & AAAGAATGGTAGTTTTTGTAGT & \multirow[t]{2}{*}{55} \\
\hline & & $\mathrm{U}$ & CAAACATATACACACTTCCA & \\
\hline & & M & AAAGAGCGGTAGTTTTCGTAGC & \multirow[t]{2}{*}{55} \\
\hline & & M & CGAACATATACACGCTTCCG & \\
\hline
\end{tabular}

forward, 5'-CAAGTTGAATGGTTAGTCTGGC-3', and reverse, 5'-GCTGGCAGAAGAGGGAGTAC-3'; and PCR conditions were $94^{\circ} \mathrm{C}$ for $10 \mathrm{~min}, 30$ cycles of $94^{\circ} \mathrm{C}$ for $30 \mathrm{sec}$, $60^{\circ} \mathrm{C}$ for $30 \mathrm{sec}$, and $72^{\circ} \mathrm{C}$ for $30 \mathrm{sec}$, then $72^{\circ} \mathrm{C}$ for $5 \mathrm{~min}$. The GenBank accession number of Timp-1 is NW_048034.

Semi-quantitative RT-PCR. In order to evaluate methylationmediated gene silencing/induction, gene transcripts were quantified using semi-quantitative RT-PCR with the SuperScript III One-Step RT-PCR system (Invitrogen, Carlsbad, CA). The PCR conditions, primer sequences and GenBank accession numbers of each gene are shown in Table III. The primer sequences for Timp 1,2 and the glyceraldehyde phosphate dehydrogenase gene (Gapdh) were the same as previously reported (25). The expression level of Gapdh was used to determine and confirm the quality of total RNA from each cell line.

\section{Results}

Methylation status in normal rat hepatocyte cell lines. The methylation status of eight tumor-related genes in five cell lines was analyzed by MSP and methylation-specific digestion. Gel fluorograms are shown in Fig. 2, and analyzed results are listed in Table IV. There were discrepancies in the methylation status between normal hepatocyte cell lines (Clone 9 and CWSV-1) and primary cells for the genes, p16, Socs-1, Rassf1A, Hic-1, Timp-1, and Timp-3. The p16, Socs-1 and Rassf1A genes are hypermethylated in both Clone 9 and CWSV-1 cells, while primary cells showed no signs of hypermethylation in these genes.

Methylation status in rat tumor cell lines. The most frequently methylated tumor-related genes in rat tumor cell lines were RassflA (3/3, 100\%), Hic-1 (3/3, 100\%), Timp-3 (3/3, 
Table III. Primer sequences for RT-PCR.

\begin{tabular}{|c|c|c|c|c|}
\hline Gene & GenBank no. & Primer sequence $\left(5^{\prime} \rightarrow 3^{\prime}\right)$ & $\begin{array}{c}\text { Annealing } \\
\text { temperature }\left({ }^{\circ} \mathrm{C}\right)\end{array}$ & Cycles \\
\hline p16 & L81167 & $\begin{array}{l}\text { GCCGTGAGCACGAGGTG } \\
\text { CCCAGCGGAGGAGAGTAGAT }\end{array}$ & 60 & 23 \\
\hline Socs-1 & NM_145879 & $\begin{array}{l}\text { CCGCTCCCACTCTGATTACC } \\
\text { TAGTGCTCCAGCAGCTCGAA }\end{array}$ & 60 & 29 \\
\hline RassflA & AB202124 & $\begin{array}{l}\text { TTCATCTGGGGCGTCGT } \\
\text { CTGCAAGGAAGGCGGTTTCT }\end{array}$ & 60 & 26 \\
\hline Hic-1 & XM_220706 & $\begin{array}{l}\text { CCTGTGACAAGAGCTACAAG } \\
\text { ATATGACTGATGAGGTTGCG }\end{array}$ & 55 & 27 \\
\hline Dlc-1 (Arhgap-7) & XM_341444 & $\begin{array}{l}\text { GCCGCCCTTAATGTGTAGAG } \\
\text { GTCCACTTGCCGCTTATG }\end{array}$ & 60 & 28 \\
\hline Timp-1 & NM_053819 & $\begin{array}{l}\text { ACAGCTTTCTGCAACTCG } \\
\text { CTATAGGTCTTTACGAAGGCC }\end{array}$ & 56 & 20 \\
\hline Timp-2 & NM_021989 & $\begin{array}{l}\text { ATTTATCTACACGGCCCC } \\
\text { CAAGAACCATCACTTCTCTTG }\end{array}$ & 56 & 20 \\
\hline Timp-3 & NM_012886 & $\begin{array}{l}\text { GGAGCCTTGGGCACTG } \\
\text { CATCTTGCCTTCATACACGC }\end{array}$ & 60 & 23 \\
\hline Gapdh & & $\begin{array}{l}\text { AAACCCATCACCATCTTCCA } \\
\text { GGCAGTGATGGCATGGACTG }\end{array}$ & 55 & 20 \\
\hline
\end{tabular}

A.
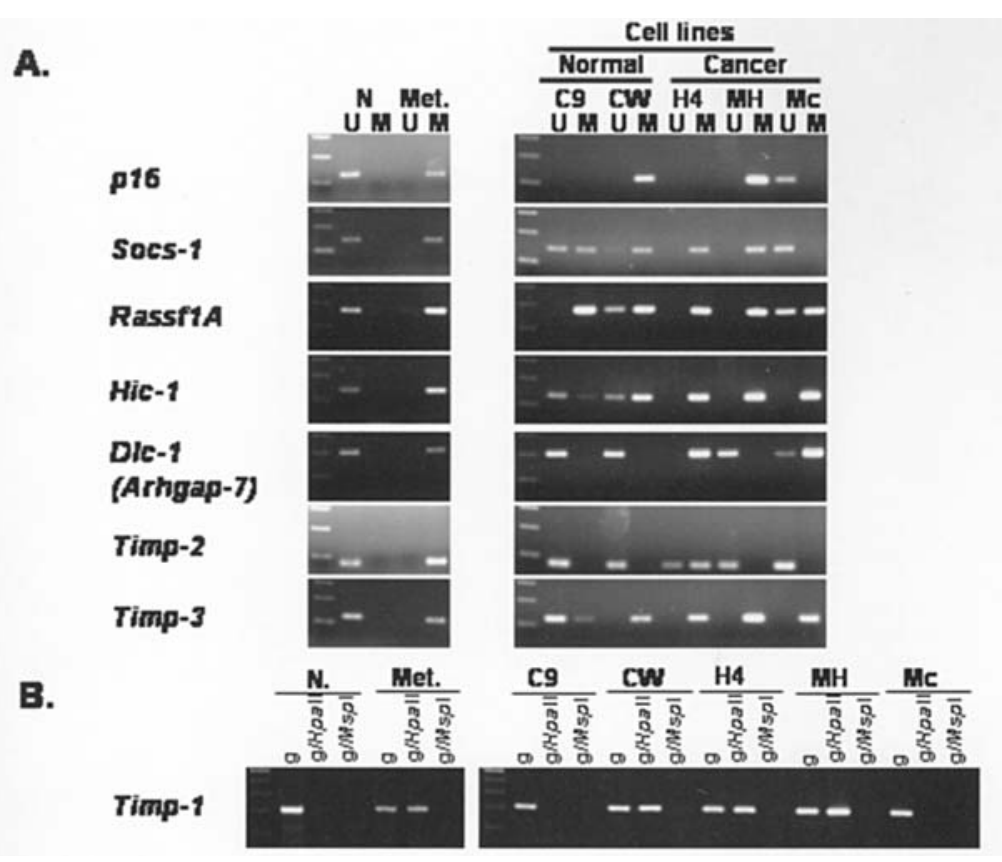

Figure 2. MSP and methylation-specific digestion/PCR results of tumor-related genes in rat hepatocytes. (A) Methylation-specific PCR and (B) methylationspecific digestion/PCR for Timp-1. N, primary cells; Met., primary cells, in vitro methylated by SssI; C9, Clone 9; CW, CWSV-1; H4, H4-II-E-C3; MH, MH1C1; Mc, McA-RH7777; U, PCR with unmethylated sequence-specific primers; M, PCR with methylated sequence-specific primers; g, PCR from genomic DNA; g/HpaII, PCR from HpaII-digested DNA; g/MspI, PCR from MspI-digested DNA.

$100 \%)$, Socs-1 $(2 / 3,67 \%)$ and Dlc-1 (2/3, 67\%) (Table IV). The 16 gene was hypermethylated in one of the two hepato- cellular carcinoma cell lines and was deleted in H4-II-E-C3 cells. The Dlc-1 and Timp-2 genes were exclusively hyper- 
Table IV. Methylation status and expression of tumor-related genes.

\begin{tabular}{|c|c|c|c|c|c|c|c|}
\hline & & \multicolumn{3}{|c|}{ Normal } & \multicolumn{3}{|c|}{ Tumor } \\
\hline & & Prim. & C 9 & $\mathrm{CW}$ & $\mathrm{H} 4$ & $\mathrm{MH}$ & $\mathrm{Mc}$ \\
\hline \multirow[t]{2}{*}{ p16 } & Methylation & $\mathrm{U}$ & ND & M & ND & M & $\mathrm{U}$ \\
\hline & Expression & ND & - & - & - & - & + \\
\hline \multirow[t]{2}{*}{ Socs-1 } & Methylation & $\mathrm{U}$ & $\mathrm{U}=\mathrm{M}$ & M & $\mathrm{M}$ & M & $\mathrm{U}$ \\
\hline & Expression & ND & + & ++ & + & + & + \\
\hline \multirow[t]{2}{*}{ RassflA } & Methylation & $\mathrm{U}$ & M & $\mathrm{U}<\mathrm{M}$ & $\mathrm{M}$ & M & $\mathrm{U}<\mathrm{M}$ \\
\hline & Expression & ND & - & + & - & - & + \\
\hline \multirow[t]{2}{*}{ Hic-1 } & Methylation & $\mathrm{U}$ & $\mathrm{U}>\mathrm{M}$ & $\mathrm{U}<\mathrm{M}$ & $\mathrm{M}$ & $\mathrm{M}$ & M \\
\hline & Expression & ND & + & - & - & - & - \\
\hline$D l c-1$ & Methylation & $\mathrm{U}$ & $\mathrm{U}$ & $\mathrm{U}$ & $\mathrm{M}$ & $\mathrm{U}$ & $\mathrm{U}<\mathrm{M}$ \\
\hline (Arhgap-7) & Expression & ND & + & ++ & - & + & - \\
\hline \multirow[t]{2}{*}{ Timp-1 } & Methylation & $\mathrm{U}$ & $\mathrm{U}$ & M & $\mathrm{M}$ & M & $\mathrm{U}$ \\
\hline & Expression & ND & + & - & - & - & + \\
\hline \multirow[t]{2}{*}{ Timp-2 } & Methylation & $\mathrm{U}$ & $\mathrm{U}$ & $\mathrm{U}$ & $\mathrm{U}<\mathrm{M}$ & $\mathrm{U}$ & $\mathrm{U}$ \\
\hline & Expression & ND & ++ & + & - & + & - \\
\hline \multirow[t]{2}{*}{ Timp-3 } & Methylation & $\mathrm{U}$ & $\mathrm{U}>\mathrm{M}$ & M & $\mathrm{M}$ & M & M \\
\hline & Expression & ND & + & - & - & - & - \\
\hline
\end{tabular}

Normal, normal cells; tumor; tumor cells; prim., primary cells in normal liver tissue; C9, Clone 9; CW, CWSV-1; H4, H4-II-E-C3; MH, MH1C1; Mc, McA-RH7777; U, unmethylated; ND, not determined; M, methylated. The population difference between unmethylated and methylated sequences are shown by $>,<$, or $=$ when both unmethylated and methylated primers amplify products in MSP. The expression level of each gene is shown from - to ++.

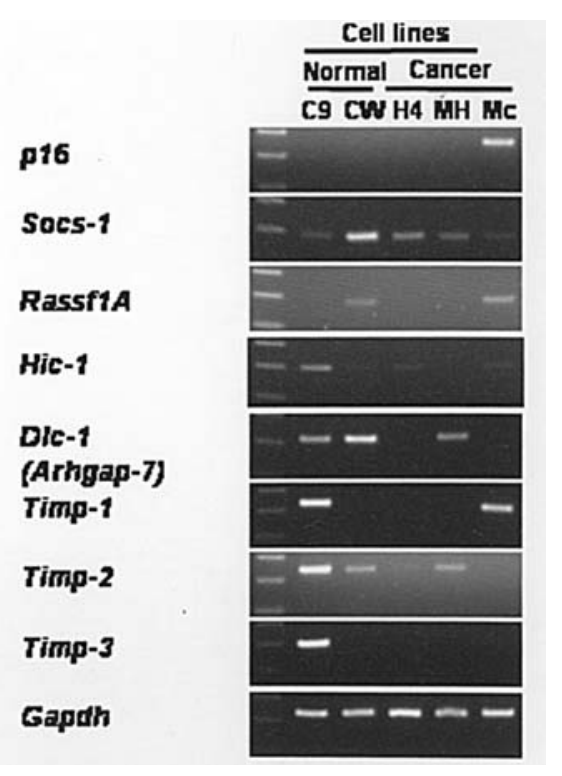

Figure 3. Expression of tumor-related genes as determined by semi-quantitative RT-PCR. C9, Clone 9; CW, CWSV-1; H4, H4-II-E-C3; MH, MH1C1; and Mc, McA-RH7777.

methylated in hepatocellular carcinoma cell lines compared to normal hepatocyte cell lines. The Timp-2 gene was aberrantly and solely hypermethylated in H4-II-E-C3 cells.
Methylation status and expression of tumor-related genes. The gel fluorogram for RT-PCR analysis of gene transcripts indicated that expression level and methylation status correlated well, except for that of the Socs-1 and Timp-2 genes (Fig. 3 and Table IV). In CWSV-1 cells, expression of the Socs-1 gene was slightly higher than that of the other genes but it did not correlate with methylation status. The Timp-2 gene was unmethylated but not expressed in McARH7777 cells.

\section{Discussion}

DNA methylation plays a crucial role in repression of tumor suppressor genes in many cancers, including hepatocellular carcinoma. Thus, a growing number of genes have been shown to be hypermethylated and repressed in hepatocarcinogenesis. Several investigators have reported the methylation profiles of human HCC (26-28), demonstrating the accumulation of aberrant DNA methylation during multistep hepatocarcinogenesis. In rat HCC models, both exogenous and endogenous factors are committed to carcinogenesis; however, the underlying mechanism is still largely obscure. Rat genome sequencing has been completed (29), and it is possible to study the rat counterpart of human tumor-related genes.

Established cell lines have been conveniently used to study carcinogenic and tumoricidal mechanisms, and cancer epigenetic studies are no exception. Therefore, the purpose of 
this study was to provide data illustrating that cell lines employed in rat cancer model studies may not always represent the situation in cancer tissues in vivo in terms of DNA methylation status. Previously, such a discrepancy has been pointed out in human cancer cells (30). The present study shows that, in primary liver cells isolated from rat liver tissue, none of the selected eight genes were hypermethylated in their promoter $\mathrm{CpG}$ islands; however, there was at least one hypermethylated gene in the cell lines (Table IV). It is also noteworthy that hypermethylation in Socs-1, Rassf1A, Hic-1, and Timp-3 was widespread among the cell lines tested but not among primary and Clone 9 cells, suggesting that Clone 9 cells are close to normal cells in terms of DNA methylation.

Although the primary objective of this report was to provide methylation profile data for selected cell lines, it is necessary to discuss the cause and outcome of aberrant methylation in each gene. p16: in human HCC, two major tumor-suppressor pathways of p16/retinoblastoma (RB) and p53/p21 are frequently altered $(7,8)$. The $p 16$ gene is known to be inactivated by mutations, homozygous deletion, or promoter hypermethylation. The homozygous deletion of this gene was found in 7-30\% of human HCC tissues and 0-29\% in human HCC cell lines $(7,31)$. In our study, the probable homozygous deletion of $p 16$ was found in the normal Clone 9 hepatocyte cell line and one of three HCC cell lines (33\%), i.e. H4-II-EC3 cells. Promoter hypermethylation of the p16 gene was found in one of the three HCC cell lines (33\%), i.e. $\mathrm{MH} 1 \mathrm{C} 1$ cells. It is possible that hypermethylation of the $p 16$ gene in the normal hepatocyte cell line was achieved during in vitro growth, similar to the case in a previous study on normal breast epithelial cells (32).

Socs-1, RassflA, Hic-1, Timp-1, and Timp-3 genes in normal Clone 9 and CWSV-1 hepatocyte cell lines are altered from the early stage of culture. The possible reasons are as follows: 1) normal tissue is a mixture of various kinds of cells, such as epithelial cells and interstitial cells, each of which could have different methylation patterns; 2) in developing cell lines, some genes become silenced by methylation because the expression of genes is no longer essential (33); and 3) aberrant DNA methylation of some genes, such as $p 16$, is critical for autonomous growth in vitro $(34,35)$. The SOCS-1 protein was discovered to be involved in a negative feedback loop of cytokine signaling $(18,36,37)$. This gene was found to be frequently hypermethylated and repressed in human HCC (38). In our study, promoter hypermethylation of the Socs-1 gene was found in many cell lines, however, the correlation between methylation and gene expression was poor (Table IV). Because DNA methylation in exon 2 of the SOCS-1 gene has been shown to regulate its expression in human HCC (39), methylation might also be important in rat HCC cell lines. Our data indicate that Socs-1 and RassflA were aberrantly hypermethylated in both normal hepatocyte cell lines, Clone 9 and CWSV-1. Supporting our data, hypermethylation of the SOCS-1 gene was even shown in normal liver tissue (27). Previously, RassflA has been shown to be heterogeneously hypermethylated in non-tumor tissue (40).

Hic- 1 was identified by Wales et al in 1995 (20), and DNA hypermethylation at the D17S5 locus and its reduced expression have been shown in human HCC (41). The present study shows that Hic-l is frequently hypermethylated in rat liver cell lines, including the normal CWSV-1 hepatocyte cell line. Because the $p 53$ gene is inactivated in CWSV-1 cells, Hic-1 may cooperate with the p53 but not the p16 locus (42). However, the fact that both Hic-1 and pl6 are hypermethylated and inactivated in this study is not consistent with this notion.

Timp-1, -2 , and -3 are physiologic tissue inhibitors of the metalloproteinases called Timp, of which four different forms are known in rats. An imbalance between matrix metalloproteinases (MMPs) and Timp is linked to the degeneration of the extracellular matrix associated with angiogenesis, invasion and metastasis (22). Because Timp-4 is known to not be expressed in the liver (43), we studied Timp-1, -2, and -3. In Timp-2, there was only a fair correlation between methylation status and gene expression. However, in the human Timp-2 gene, it was thought that methylation of the promoter $\mathrm{CpG}$ island has no influence on gene expression (44). Aberrant methylation in the human Timp-3 gene is well documented in many cancers $(45,46)$. In rat HCC cell lines, we showed that Timp-3 was frequently hypermethylated $(3 / 3,100 \%)$. However, in a normal CWSV-1 hepatocyte cell line, Timp-3 was also aberrantly hypermethylated. In human HCC, the Timp-1 protein concentration is reported to be higher or similar in HCC as compared to normal tissue (47-49). It was also shown that the Timp- 1 protein has the ability to reduce metastasis (50). Our study showed that Timp- 1 was frequently hypermethylated and repressed in rat HCC cell lines $(2 / 3,67 \%)$, and this is the first report describing the aberrant hypermethylation of the Timp-1 gene in HCC. Furthermore, Timp-1 has been shown to exist on the $\mathrm{X}$ chromosome, and DNA methylation regulates its expression (51). The gender of the MH1C1 and McARH7777 cell lines that we used was female. Thus, they should have had one methylated X chromosome and one unmethylated $\mathrm{X}$ chromosome before developing cancer, while the MH1C1 cell line only has a methylated X chromosome and McARH7777 only has an unmethylated X chromosome. In the present study, we saw a distinct change in aberrant methylation in each HCC cell line. These cells could be good cellular models to study aberrant gene methylation on the $\mathrm{X}$ chromosome during hepatocarcinogenesis.

Dlc- 1 was identified by Yuan et al and previously shown to be frequently hypermethylated or deleted in human HCC $(21,52)$. It has $80 \%$ homology with rodent Arhgap-7, a GTPaseactivating protein for Rho family proteins. It was also demonstrated that the ectopic expression of Dlc- 1 inhibits cell growth and migration in vitro and induces apoptosis and reduces tumorigenecity in vivo (53). In this study, the Dlc- 1 gene was not deleted but frequently and specifically hypermethylated in HCC cell lines, suggesting that this gene may play a critical role in rat hepatocarcinogenesis. Although CWSV-1 cells are not transplantable to nude mice (54), they become tumorigenic and transplantable when cultivated in choline-deficient medium (17). Dlc- 1 could be a candidate gene involved this process. In summary, we report a cautionary note that DNA methylation profiles in established cell lines may not be the same in vivo.

\section{Acknowledgements}

We are grateful for the partial support of this research provided by grant CA082506 (Robert A. Floyd) from the National Cancer Institute, NIH, USA. 


\section{References}

1. Briand P and Lykkesfeldt AE: An in vitro model of human breast carcinogenesis: epigenetic aspects. Breast Cancer Res Treat 65: 179-187, 2001 .

2. Katdare M, Osborne MP and Telang NT: Novel cell culture models for prevention of human breast cancer (Review). Int J Oncol 22: 509-515, 2003.

3. Schrump DS and Nguyen DM: Targeting the epigenome for the treatment and prevention of lung cancer. Semin Oncol 32: 488-502, 2005

4. Marian B: In vitro models for the identification and characterization of tumor-promoting and protective factors for colon carcinogenesis. Food Chem Toxicol 40: 1099-1104, 2002.

5. Stampfer MR and Yaswen P: Human epithelial cell immortalization as a step in carcinogenesis. Cancer Lett 194: 199-208, 2003.

6. Lambert JD, Hong J, Yang GY, Liao J and Yang CS: Inhibition of carcinogenesis by polyphenols: evidence from laboratory investigations. Am J Clin Nutr 81: 284S-291S, 2005.

7. Tannapfel A, Busse C, Weinans L, et al: INK4a-ARF alterations and p53 mutations in hepatocellular carcinomas. Oncogene 20: 7104-7109, 2001

8. Ito T, Nishida N, Fukuda Y, Nishimura T, Komeda T and Nakao K: Alteration of the p14(ARF) gene and p53 status in human hepatocellular carcinomas. J Gastroenterol 39: 355-361, 2004.

9. Locker J, Hutt S and Lombardi B: Alpha-fetoprotein gene methylation and hepatocarcinogenesis in rats fed a choline-devoid diet. Carcinogenesis 8: 241-246, 1987.

10. Lopatina NG, Vanyushin BF, Cronin GM and Poirier LA: Elevated expression and altered pattern of activity of DNA methyltransferase in liver tumors of rats fed methyl-deficient diets. Carcinogenesis 19: 1777-1781, 1998.

11. Motiwala T, Ghoshal K, Das A, et al: Suppression of the protein tyrosine phosphatase receptor type O gene (PTPRO) by methylation in hepatocellular carcinomas. Oncogene 22: 6319-6331, 2003.

12. Pogribny IP and James SJ: De novo methylation of the $\mathrm{p} 16^{\mathrm{INK} 4 \mathrm{~A}}$ gene in early preneoplastic liver and tumors induced by folate/ methyl deficiency in rats. Cancer Lett 187: 69-75, 2002.

13. Steinmetz KL, Pogribny IP, James SJ and Pitot HC: Hypomethylation of the rat glutathione S-transferase pi (GSTP) promoter region isolated from methyl-deficient livers and GSTP-positive liver neoplasms. Carcinogenesis 19: 1487-1494, 1998.

14. Tsujiuchi T, Tsutsumi M, Sasaki Y, Takahama M and Konishi Y: Hypomethylation of $\mathrm{CpG}$ sites and c-myc gene overexpression in hepatocellular carcinomas, but not hyperplastic nodules, induced by a choline-deficient L-amino acid-defined diet in rats. Jpn J Cancer Res 90: 909-913, 1999.

15. Zapisek WF, Cronin GM, Lyn-Cook BD and Poirier LA: The onset of oncogene hypomethylation in the livers of rats fed methyl-deficient, amino acid-defined diets. Carcinogenesis 13: 1869-1872, 1992.

16. Kempe KC, Isom HC and Greene FE: Responsiveness of an SV40-immortalized hepatocyte cell line to growth hormone. Biochem Pharmacol 49: 1091-1098, 1995.

17. Zeisel SH, Albright CD, Shin OH, Mar MH, Salganik RI and da Costa KA: Choline deficiency selects for resistance to p53independent apoptosis and causes tumorigenic transformation of rat hepatocytes. Carcinogenesis 18: 731-738, 1997.

18. Starr R, Willson TA, Viney EM, et al: A family of cytokineinducible inhibitors of signalling. Nature 387: 917-921, 1997.

19. Dammann R, Li C, Yoon JH, Chin PL, Bates S and Pfeifer GP Epigenetic inactivation of a RAS association domain family protein from the lung tumour suppressor locus $3 \mathrm{p} 21.3$. Nat Genet 25: 315-319, 2000.

20. Wales MM, Biel MA, el Deiry W, et al: p53 activates expression of HIC-1, a new candidate tumour suppressor gene on $17 \mathrm{p} 13.3$. Nat Med 1: 570-577, 1995

21. Yuan BZ, Miller MJ, Keck CL, Zimonjic DB, Thorgeirsson SS and Popescu NC: Cloning, characterization, and chromosomal localization of a gene frequently deleted in human liver cancer (DLC-1) homologous to rat RhoGAP. Cancer Res 58: 2196-2199, 1998.

22. Fassina G, Ferrari N, Brigati C, Benelli R, Santi L, Noonan DM and Albini A: Tissue inhibitors of metalloproteases: regulation and biological activities. Clin Exp Metastasis 18: 111-120, 2000 .
23. Asada K, Miyamoto K, Fukutomi T, et al: Reduced expression of GNA11 and silencing of MCT1 in human breast cancers. Oncology 64: 380-388, 2003.

24. Swafford DS, Middleton SK, Palmisano WA, et al: Frequent aberrant methylation of $\mathrm{p} 16^{\mathrm{INK} 4 \mathrm{a}}$ in primary rat lung tumors. Mol Cell Biol 17: 1366-1374, 1997.

25. Phillips PA, McCarroll JA, Park S, et al: Rat pancreatic stellate cells secrete matrix metalloproteinases: implications for extracellular matrix turnover. Gut 52: 275-282, 2003.

26. Yu J, Ni M, Xu J, et al: Methylation profiling of twenty promoter$\mathrm{CpG}$ islands of genes which may contribute to hepatocellular carcinogenesis. BMC Cancer 2: 29, 2002.

27. Yang B, Guo M, Herman JG and Clark DP: Aberrant promoter methylation profiles of tumor suppressor genes in hepatocellular carcinoma. Am J Pathol 163: 1101-1107, 2003.

28. Lee S, Lee HJ, Kim JH, Lee HS, Jang JJ and Kang GH: Aberrant $\mathrm{CpG}$ island hypermethylation along multistep hepatocarcinogenesis. Am J Pathol 163: 1371-1378, 2003.

29. Gibbs RA, Weinstock GM, Metzker ML, et al: Genome sequence of the Brown Norway rat yields insights into mammalian evolution. Nature 428: 493-521, 2004.

30. Ushijima T, Watanabe N, Shimizu K, Miyamoto K, Sugimura T and Kaneda A: Decreased fidelity in replicating $\mathrm{CpG}$ methylation patterns in cancer cells. Cancer Res 65: 11-17, 2005.

31. Jin M, Piao Z, Kim NG, et al: p16 is a major inactivation target in hepatocellular carcinoma. Cancer 89: 60-68, 2000.

32. Huschtscha LI, Noble JR, Neumann AA, et al: Loss of p16 $16^{\mathrm{INK} 4}$ expression by methylation is associated with lifespan extension of human mammary epithelial cells. Cancer Res 58: 3508-3512, 1998.

33. Antequera F, Boyes $\mathrm{J}$ and Bird A: High levels of de novo methylation and altered chromatin structure at $\mathrm{CpG}$ islands in cell lines. Cell 62: 503-514, 1990.

34. Foster SA, Wong DJ, Barrett MT and Galloway DA: Inactivation of p16 in human mammary epithelial cells by $\mathrm{CpG}$ island methylation. Mol Cell Biol 18: 1793-1801, 1998.

35. Jones PA, Wolkowicz MJ, Rideout WM III, Gonzales FA, Marziasz CM, Coetzee GA and Tapscott SJ: De novo methylation of the MyoD1 CpG island during the establishment of immortal cell lines. Proc Natl Acad Sci USA 87: 6117-6121, 1990

36. Endo TA, Masuhara M, Yokouchi M, et al: A new protein containing an $\mathrm{SH} 2$ domain that inhibits JAK kinases. Nature 387: 921-924, 1997.

37. Naka T, Narazaki M, Hirata M, et al: Structure and function of a new STAT-induced STAT inhibitor. Nature 387: 924-929, 1997.

38. Yoshikawa H, Matsubara K, Qian GS, et al: SOCS-1, a negative regulator of the JAK/STAT pathway, is silenced by methylation in human hepatocellular carcinoma and shows growth-suppression activity. Nat Genet 28: 29-35, 2001

39. Melzner I and Moller P: Silencing of the SOCS-1 gene by CpG methylation? Blood 102: 1554-1555, 2003.

40. Zhong S, Yeo W, Tang MW, Wong N, Lai PB and Johnson PJ: Intensive hypermethylation of the $\mathrm{CpG}$ island of Ras association domain family $1 \mathrm{~A}$ in hepatitis B virus-associated hepatocellular carcinomas. Clin Cancer Res 9: 3376-3382, 2003.

41. Kanai Y, Hui AM, Sun L, Ushijima S, Sakamoto M, Tsuda H and Hirohashi S: DNA hypermethylation at the D17S5 locus and reduced HIC-1 mRNA expression are associated with hepatocarcinogenesis. Hepatology 29: 703-709, 1999.

42. Chen W, Cooper TK, Zahnow CA, et al: Epigenetic and genetic loss of Hic1 function accentuates the role of p53 in tumorigenesis. Cancer Cell 6: 387-398, 2004.

43. Greene J, Wang M, Liu YE, Raymond LA, Rosen C and Shi YE Molecular cloning and characterization of human tissue inhibitor of metalloproteinase 4. J Biol Chem 271: 30375-30380, 1996.

44. Hammani K, Blakis A, Morsette D, Bowcock AM, Schmutte C, Henriet P and DeClerck YA: Structure and characterization of the human tissue inhibitor of metalloproteinases- 2 gene. J Biol Chem 271: 25498-25505, 1996.

45. Cameron EE, Bachman KE, Myohanen S, Herman JG and Baylin SB: Synergy of demethylation and histone deacetylase inhibition in the re-expression of genes silenced in cancer. Nat Genet 21: 103-107, 1999 .

46. Esteller M, Corn PG, Baylin SB and Herman JG: A gene hypermethylation profile of human cancer. Cancer Res 61: 3225-3229, 2001 .

47. Matsumoto E, Nakatsukasa H, Nouso K, et al: Increased levels of tissue inhibitor of metalloproteinase-1 in human hepatocellular carcinoma. Liver Int 24: 379-383, 2004. 
48. Yamamoto $\mathrm{H}$, Itoh $\mathrm{F}$, Adachi $\mathrm{Y}$, et al: Messenger RNA expression of matrix metalloproteinases and tissue inhibitors of metalloproteinases in human hepatocellular carcinoma. Jpn J Clin Oncol 29: 58-62, 1999.

49. Nakatsukasa H, Ashida K, Higashi T, et al: Cellular distribution of transcripts for tissue inhibitor of metalloproteinases 1 and 2 in human hepatocellular carcinomas. Hepatology 24: 82-88, 1996.

50. Yamauchi K, Ogata Y, Nagase H and Shirouzu K: Inhibition of liver metastasis from orthotopically implanted colon cancer in nude mice by transfection of the TIMP-1 gene into KM12SM cells. Surg Today 31: 791-798, 2001.

51. Anderson CL and Brown CJ: Variability of X chromosome inactivation: effect on levels of TIMP1 RNA and role of DNA methylation. Hum Genet 110: 271-278, 2002.
52. Yuan BZ, Durkin ME and Popescu NC: Promoter hypermethylation of DLC-1, a candidate tumor suppressor gene, in several common human cancers. Cancer Genet Cytogenet 140: 113-117, 2003.

53. Zhou X, Thorgeirsson SS and Popescu NC: Restoration of DLC-1 gene expression induces apoptosis and inhibits both cell growth and tumorigenicity in human hepatocellular carcinoma cells. Oncogene 23: 1308-1313, 2004.

54. Weinstein IB, Orenstein JM, Gebert R, Kaighn ME and Stadler UC: Growth and structural properties of epithelial cell cultures established from normal rat liver and chemically induced hepatomas. Cancer Res 35: 253-263, 1975.

55. Reuber MD: A transplantable bile-secreting hepatocellular carcinoma in the rat. J Natl Cancer Inst 26: 891-899, 1961. 